\title{
Organic phosphate in UK rivers and its relevance to algal and bryophyte surveys
}

\author{
Brian A. Whitton ${ }^{1 *}$ and Colin $\mathrm{Neal}^{2}$ \\ ${ }^{1}$ School of Biological and Biomedical Sciences, University of Durham, Durham DH1 3LE, UK \\ 2 Centre for Ecology and Hydrology, McLean Building, Crowmarsh Gifford, Wallingford OX10 8BB, UK
}

Received 9 October 2010; Accepted 6 December 2010

\begin{abstract}
Although the data on phosphate obtained in surveys are used to assess the distribution of river biota, the approach is flawed when the organisms use $\mathrm{P}$ fractions not included in routine analysis. This is especially important where aquatic phototrophs are partially or largely dependent on aqueous organic phosphate. This paper reports a study where the data are sufficient to assess the quantitative importance of organic phosphate in rivers in eastern UK. Filterable hydrolyzable phosphate-P (FHP) is used as a surrogate for organic phosphate, although FHP sometimes includes other P forms. Eighteen sites were sampled weekly for at least one, but mostly three years (2033 samples). The data are compared for mid- and lower-reach sites. FHP formed at least 20\% TFP (total filterable phosphate-P) at 14 sites, with the percentage values higher at the more upstream and more northern sites. FHP exceeded $1000 \mu \mathrm{g} . \mathrm{L}^{-1} \mathrm{P}$ in 32 mid- and 53 lower-reach records. The lower the TFP concentration, the higher the \% FHP at both types of site. Five sites had over $25 \%$ of their records where FHP is likely to be especially important for growth of algae and bryophytes, based on FHP being $>50 \mu \mathrm{g} . \mathrm{L}^{-1} \mathrm{P}$ when TFP $\leq 200 \mu \mathrm{g} . \mathrm{L}^{-1} \mathrm{P}$. These include the upper site on River Swale, and other literature for this river indicates that FHP becomes increasingly important further upstream and even more so in tributary streams. FHP should be included in monitoring programmes for upland rivers, especially where the catchment includes peat-rich soils.
\end{abstract}

Key words: Organic phosphate / rivers / peat / algae / monitoring

\section{Introduction}

During the past twenty years, evidence has emerged that organic phosphorus is often as abundant as, and sometimes in excess of, inorganic phosphate in water and sediment systems. Further, the organic phosphorus may be much less refractory than previously supposed (McElvie, 2005; Turner, 2005) and there is also considerable evidence for the use of organic phosphates by aquatic organisms (Heath, 2005; Whitton et al., 2005). In the case of cyanobacteria, eukaryotic algae and aquatic bryophytes this evidence includes experimental studies on the ability to utilize organic phosphates (Whitton et al., 1991), assays of surface phosphatase activity of field samples and laboratory cultures and correlations between the occurrence of particular taxa and water in which organic phosphate is probably the main form of phosphate (Whitton et al., 2005; Mateo et al., 2010). Further, some organic forms of phosphorus can break down quite

\footnotetext{
*Corresponding author: b.a.whitton@durham.ac.uk
}

rapidly in water (Denison et al., 1998) and analysis of inorganic phosphate using standard phosphomolybdate methodologies can include a significant component due to breakdown of organic phosphorus (Baldwin, 1998).

There are, however, few direct measurements of organic phosphate in freshwaters. Most information in the literature depends on the assumption that it corresponds to the phosphate fraction released by persulphate digestion of a filtered water sample, though this needs to be treated with caution: see below. We will therefore refer to this fraction as filterable hydrolyzable phosphate (FHP: Table 1). Accounts of nutrients in aquatic biology journals usually report either total phosphate (TP) or filterable reactive phosphate (FRP), making it impossible to estimate filterable hydrolyzable phosphate. This is especially the case for routine surveys by most water management organizations in Europe, including many studies related to the Water Framework Directive (Directive 2000/60/EC, 23 October 2000). This situation occurs for a number of reasons. For example, there is the additional effort (and cost) that would be involved, there is instability of dissolved 
phosphorus after sample collection and rapid analysis is required and also because of the complexity of phosphate chemistry in water. Further, within a water management setting, the importance of phosphorus enrichment from sewage and agricultural sources with a high inorganic phosphorus loading makes it the centre of attention and especially for lowland areas where it is perceived that the major problems lie. This is also underpinned by the weak understanding of the biological use of the various phosphorus fractions when it comes to implement legislation such as the Water Framework Directive.

In order to interpret the literature, some understanding of the analytical methods is needed (Jarvie et al., 2002). The method of phosphorus analysis is often based on a colourimetric technique using phosphomolybdic acid methodologies stemming from the work of Murphy and Riley (1962). Based on procedures in manuals such as that of the American Public Health Association (2005), a filtered, but otherwise untreated sample, assayed by this procedure (filterable reactive phosphorus: FRP) is usually treated as inorganic phosphate and the fraction released by persulphate digestion (Lambert and Maher, 1994) as organophosphorus. Note that the assay following persulphate digestion (total filterable phosphorus, TFP) is the sum of FRP and FHP, the FHP being estimated as the difference between TFP and FRP. FRP may, however, include labile organic compounds (McElvie, 2005), while FHP may also include condensed inorganic phosphates (Denison et al., 1998). (See Table 1 for the original terminology for $\mathrm{P}$ fractions used by other authors.) Further, the separation between dissolved and particulate fractions is defined operationally, as the results are influenced by the filtration procedure. Even the filterable phosphate fraction may include a colloidal component (Haygarth et al., 1997) and there is a lack of information on the differences among algae and bryophytes in their ability to utilize this.

Studies on unpolluted upland streams in north-east England draining peaty catchments have shown that FHP often constitutes the major part of the filterable phosphate in the water (Turner et al., 2003; Ellwood et al., 2007, 2008). In streams draining peaty catchments, the FHP concentration is sometimes especially high for short periods in spring, even reaching $1000 \mu \mathrm{g} . \mathrm{L}^{-1} \mathrm{P}$ near the source in those dominated by the cyanobacterium Rivularia, which shows high surface phosphatase activity (Livingstone and Whitton, 1984) and can use organic phosphates during growth in culture. Values almost as high were found here during a study of the surface phosphatase activities of mosses in the same streams in 1999-2000 (Turner et al., 2003). The literature on algal and bryophyte studies reviewed by Whitton et al. (2005), and also later papers quoted in the Discussion, shows that there is a marked tendency for their surface phosphatase activities to be higher the greater the percentage FHP in the TFP fraction. This effect is evident when comparisons are made between sites in the same river sampled on the same day or between months for a population sampled from one particular site.
In order to obtain a broader view of the distribution of phosphate fractions in flowing waters in different catchments we searched the literature for large datasets and decided to re-assess a large dataset for UK Rivers which does include FHP. This formed part of the Land-Ocean Interaction Study (LOIS), which relates to eastern UK Rivers entering the North Sea (Leeks et al., 1997). It did not include upland streams, but did include data for the middle stretches of rivers draining peaty catchments. Detailed studies have been reported on many of the chemical components of the water (e.g. Jarvie et al., 1998; Neal et al., 2000a), but only limited assessment of FHP. Jarvie et al. (1998) concluded that, whereas FRP showed marked dilution with increased flow, this did not occur with FHP, so the ratio FRP:FHP decreases rapidly with increasing flow. FHP formed a higher proportion of TFP in the northern rivers, which drain more agricultural/rural areas, than in the southern urban/industrial rivers. The authors also commented that there appear to be two different populations of points on a FRP versus TFP plot: those which lie on a straight line close to unity and those which, for a given TFP have much lower FRP concentration and thus a higher FHP concentration. A detailed assessment (House and Warwick, 1998) of one of the northern rivers, R. Swale, found that the ratio FHP:FRP was particularly low in low flow periods in October and April. In contrast FHP formed a particularly high proportion of TFP during a storm event in February 1996.

The aim of this paper is to report and comment on the results for the two phosphate fractions, FHP and FRP, obtained during the LOIS project and to assess the implications for future studies, especially biological surveys including routine monitoring.

\section{Methods}

\section{Monitoring programme}

An overall account of the LOIS project is given by Leeks et al. (1997) and of the monitoring programme by Neal and Robson (2000). Although this extended from 1993 to 1998, not all the rivers were surveyed for the same period. Two main eastern UK basins were examined. The River Tweed (including a tributary, the Teviot) on the England-Scotland borders has a largely rural catchment (Robson and Neal, 1997). The Humber has a range of rural, agricultural and urban/industrial settings (Jarvie et al., 1998). During a late stage of the LOIS the study was extended to three other rivers, data for which are included here, the upper half of the River Wear in northern England with a moorland catchment and mining legacy (Neal et al., 2000b) and two lowland agricultural rivers in southern England, the Great Ouse (Neal et al., 2000c) and the Thames (Neal et al., 2000d). Wherever possible, samples were collected in areas of higher current speed to avoid dead-zones and obtain more representative measurements. This usually involved mid-river sampling at bridges. 
Table 1. Nomenclature of phosphorus fractions considered here and comparison with the original terms used in the literature quoted. Abbreviations not explained in table: $\mathrm{DHP}=$ dissolved hydrolyzable phosphate-P; SRP = soluble reactive phosphate-P; $\mathrm{SUP}=$ soluble unreactive phosphate-P; FOP $=$ filterable organic phosphate-P; TDP = total dissolved phosphate-P.

\begin{tabular}{|c|c|c|c|c|c|}
\hline & \multirow{2}{*}{$\begin{array}{l}\text { Nomenclature } \\
\text { in this paper }\end{array}$} & \multicolumn{4}{|c|}{ Nomenclature in literature } \\
\hline & & $\begin{array}{l}\text { Jarvie et al. } \\
(1998,2010)\end{array}$ & $\begin{array}{c}\text { House and } \\
\text { Warwick (1998) }\end{array}$ & $\begin{array}{c}\text { Ellwood and } \\
\text { Whitton (2007a) }\end{array}$ & $\begin{array}{l}\text { Withers } \\
\text { et al. }(2007)\end{array}$ \\
\hline Filterable reactive phosphate-P & FRP & SRP & SRP & FRP & DRP \\
\hline Filterable hydrolyzable phosphate-P & FHP & DHP & SUP & FOP & DUP \\
\hline Total filterable phosphate-P & TFP & TDP & TDP & TFP & TDP \\
\hline Total phosphate-P & $\mathrm{TP}$ & $\mathrm{TP}$ & $\mathrm{TP}$ & $\mathrm{TP}$ & $\mathrm{TP}$ \\
\hline
\end{tabular}

Middle and lower parts of the rivers were monitored, which are denoted here as mid-reaches and lower-reaches.

\section{Dataset}

A total of 2033 samples were obtained from 18 sites, with 978 samples from mid-reach and 1055 from lowerreach sites. The totals for individual sites are shown in Table 2. Nutrient input upstream of the mid-reach sites is mainly rural and agricultural, whereas lower-reach sites also include many domestic and often also industrial sources. A broadly similar sampling programme was used for most sites, but for various practical reasons the totals for individual sites differ slightly. Different programmes were used for the Rivers Wear, Great Ouse and Thames leading to a reduced number of samples, but it was decided to include the data in the overall analysis, because sampling was done for at least a year and provided a wider range of environments.

\section{Analytical methods and terminology}

Details of sampling, storage and analysis can be found in Jarvie et al. (1998) and House and Warwick (1998), so only brief details are given here. Samples were kept cool and in the dark from collection to analysis. They were filtered either in the field or on immediate return to the laboratory with sterile $0.45 \mu \mathrm{m}$ filters (Whatman cellulose nitrate). FRP and TFP were usually measured on the same day, the latter involving persulphate digestion by a slightly modified version of Eisenreich et al. (1975). Where this was impossible, persulphate was added immediately after sampling and filtration, and the sample was then stored overnight in the dark at $4{ }^{\circ} \mathrm{C}$, with analysis done the next morning. Speedy analysis is important due to the need to reduce possible changes (Jarvie et al., 2002), such as hydrolysis of organic phosphates by phosphatases. Phosphate was measured colourimetrically according to Murphy and Riley (1962) with a 2- or 4-cm cell, which gives a detection limit of about 7 or $3 \mu \mathrm{g} . \mathrm{L}^{-1} \mathrm{P}$, respectively.

Two sets of TFP (and hence FHP) measurements were taken for the R. Wear. When TFP was not measured until the next day a major portion of the FHP was lost, although in absolute rather than percentage terms the differences were less significant. In the current study we only use the data for where the TFP was measured on the same day of sampling (Neal et al., 2000b).

The terms used to describe various phosphate fractions in water are summarized in Table 1 . A variety of terms have been used in the literature for what are broadly similar fractions. We use "filterable" here rather than "soluble" to reflect that there may be colloidal fractions that pass through the filters.

\section{Results}

The data for all $\mathrm{P}$ fractions are summarized in Table 2 where average, median, minimum and maximum values are presented. The average and median values are highly linearly correlated with intercepts statistically insignificantly different from zero. For FRP and TFP the gradients are insignificantly different from unity $\left(1.01 \pm 0.03, r^{2}=0.992\right.$, and $1.00 \pm 0.04, r^{2}=0.986$, respectively). However, in the case of FHP the median concentrations are around a half of the average, the gradient being $0.53 \pm 0.04\left(r^{2}=0.918\right)$ but this barely affects the estimate for the average percentage FHP in the TFP (Table 2). To simplify the text only the averages will be referred to in the remaining script. FHP formed $20 \%$ or more of TFP at 13 of the 18 sites, although it sometimes occurred at or below the detection limit for individual measurements at all but two sites. The percentage values tended to be higher in the mid-reach and more northern sites, where the catchments have a higher proportion of moorland and a much lower population density. FHP exceeded $1000 \mu \mathrm{g} . \mathrm{L}^{-1} \mathrm{P}$ in 32 records for the mid-reach sites and 53 records for lower-reach sites (3.1 and $4.6 \%$ total records, respectively) (Table 3). In six of the mid-reach sites with high FHP, FRP was $<200 \mu$ g. $\mathrm{L}^{-1}$ P. FHP as $\%$ TFP became increasingly more important the lower the value for TFP for both mid-reach and lower-reach sites (Fig. 1).

In order to establish where FHP makes a high enough contribution to TFP to be of potential importance for growth of algae and bryophytes, a comparison was made between sites for the number of records with various combinations of FHP and TFP concentrations. As an example, those with FHP $>50 \mu \mathrm{g} . \mathrm{L}^{-1}$ and TFP $<200 \mu \mathrm{g} . \mathrm{L}^{-1}$ are shown in Table 3 . Five of the 18 sites, all mid-reach, had over $25 \%$ records with this combination. 
Table 2. Summary of data on $\mathrm{P}$ fractions; concentrations in $\mu \mathrm{g} . \mathrm{L}^{-1} \mathrm{P}$. Sites are grouped as mid-reach and lower-reach according to their predominant catchment and then arranged in approximate sequence from north to south and upstream to downstream. Value for FHP as \% TFP is estimated from mean of individual \% values. $n=$ number of records for site, avg $=$ average, med $=$ median.

\begin{tabular}{|c|c|c|c|c|c|c|c|c|c|c|c|c|c|c|c|}
\hline \multirow[b]{2}{*}{ River, site } & \multirow[b]{2}{*}{$n$} & \multicolumn{4}{|c|}{ FRP } & \multicolumn{4}{|c|}{ FHP } & \multicolumn{4}{|c|}{ TFP } & \multicolumn{2}{|c|}{ FHP $\%$ TFP } \\
\hline & & avg & med & $\min$ & $\max$ & avg & med & $\min$ & $\max$ & avg & med & $\min$ & $\max$ & avg & med \\
\hline \multicolumn{16}{|l|}{ Mid-Reach } \\
\hline Teviot, Ormiston Mill & 98 & 37 & 30 & $\leq 3$ & 128 & 53 & 25 & $\leq 3$ & 1116 & 89 & 58 & $\leq 3$ & 1188 & 41 & 40 \\
\hline Tweed, Boleside & 90 & 35 & 23 & $\leq 3$ & 272 & 44 & 22 & $\leq 3$ & 1176 & 80 & 50 & $\leq 3$ & 1207 & 44 & 40 \\
\hline Tweed, Norham & 101 & 31 & 28 & $\leq 3$ & 85 & 68 & 21 & $\leq 3$ & 1371 & 99 & 53 & $\leq 3$ & 1395 & 44 & 42 \\
\hline Wear, Sunderland Br. & 55 & 325 & 301 & 42 & 944 & 64 & 45 & $\leq 3$ & 354 & 389 & 343 & $\leq 3$ & 964 & 19 & 18 \\
\hline Swale, Catterick Br. & 176 & 104 & 69 & $\leq 3$ & 1050 & 105 & 26 & $\leq 3$ & 1709 & 209 & 100 & $\leq 3$ & 1914 & 34 & 28 \\
\hline Swale, Thornton Man & 130 & 213 & 189 & 29 & 578 & 66 & 43 & $\leq 3$ & 1359 & 278 & 251 & $\leq 3$ & 1566 & 23 & 16 \\
\hline Ure, Boroughbridge & 129 & 63 & 55 & $\leq 3$ & 170 & 131 & 35 & $\leq 3$ & 2031 & 194 & 94 & $\leq 3$ & 2086 & 41 & 35 \\
\hline Nidd, Skip Br. & 132 & 579 & 562 & 38 & 1687 & 171 & 71 & $\leq 3$ & 1755 & 751 & 705 & $\leq 3$ & 2476 & 20 & 14 \\
\hline Wharfe, Tadcaster & 136 & 192 & 161 & 23 & 466 & 116 & 44 & $\leq 3$ & 2292 & 309 & 243 & $\leq 3$ & 2344 & 28 & 21 \\
\hline \multicolumn{16}{|l|}{ Lower-Reach } \\
\hline Derwent, Bubwith & 118 & 147 & 138 & 26 & 370 & 95 & 40 & $\leq 3$ & 1606 & 242 & 214 & $\leq 3$ & 1713 & 30 & 23 \\
\hline Ouse, Clifton Br. & 131 & 224 & 190 & 37 & 875 & 117 & 47 & $\leq 3$ & 1514 & 341 & 256 & $\leq 3$ & 1775 & 25 & 18 \\
\hline Ouse, Acaster & 127 & 371 & 273 & 47 & 1150 & 162 & 55 & $\leq 3$ & 1823 & 533 & 350 & $\leq 3$ & 2928 & 25 & 19 \\
\hline Calder, Methley Br. & 128 & 1167 & 1156 & 49 & 2699 & 374 & 208 & 19 & 1984 & 1541 & 1504 & 19 & 4166 & 23 & 18 \\
\hline Aire, Beal Br. & 140 & 1102 & 1130 & 72 & 2579 & 316 & 180 & $\leq 3$ & 2215 & 1418 & 1423 & $\leq 3$ & 3666 & 22 & 16 \\
\hline Don, Sprotborough Br. & 129 & 1585 & 1548 & 38 & 3505 & 335 & 191 & $\leq 3$ & 2142 & 1920 & 1918 & $\leq 3$ & 4008 & 17 & 11 \\
\hline Trent, Cromwell Lock & 126 & 1726 & 1820 & 235 & 3104 & 276 & 178 & $\leq 3$ & 2246 & 2003 & 2086 & $\leq 3$ & 3694 & 14 & 10 \\
\hline Gt Ouse, Gt Paxton & 46 & 1614 & 1697 & 222 & 3165 & 122 & 75 & $\leq 3$ & 703 & 1735 & 1880 & $\leq 3$ & 3530 & 7 & 5 \\
\hline Thames, Howbury Pk & 303 & 559 & 418 & 80 & 2100 & 26 & 18 & $\leq 3$ & 433 & 584 & 444 & $\leq 3$ & 2116 & 6 & 4 \\
\hline
\end{tabular}

Table 3. Comparison of records to show the relative importance of FHP at each site.

I: Total records for TFP $<200 \mu \mathrm{g}$. $\mathrm{L}^{-1}$ to indicate sites where the concentration of this fraction is low.

II: Total records combining FHP $>50 \mu \mathrm{g} . \mathrm{L}^{-1}$ and TFP $<200 \mu \mathrm{g} . \mathrm{L}^{-1}$ to show sites where FHP may make an important contribution to phosphate supply for phototrophs.

III: Total records for FHP $>1000 \mu \mathrm{g} . \mathrm{L}^{-1}$ to indicate sites where this fraction is quantitatively important. "Upland" and "Lowland" refer to the predominant catchment upstream of the site and not the site itself (i.e. correspond to Mid-Reach and Lower-Reach in Table 2).

\begin{tabular}{|c|c|c|c|}
\hline \multirow[b]{2}{*}{ River, Site } & \multicolumn{3}{|c|}{ Records } \\
\hline & $\mathrm{TFP} \leq 200 \mu \mathrm{g} \cdot \mathrm{L}^{-1}$ & $\begin{array}{c}\text { II } \\
\text { FHP }>50 \mu \mathrm{g} . \mathrm{L}^{-1} \\
\text { when TFP } \leq 200 \mu \mathrm{g} . \mathrm{L}^{-1}\end{array}$ & FHP $>1000 \mu \mathrm{g} . \mathrm{L}^{-1}$ \\
\hline \multicolumn{4}{|l|}{$\overline{\text { Upland }}$} \\
\hline Teviot & 88 & 32 & 1 \\
\hline Tweed, Boleside & 83 & 35 & 1 \\
\hline Tweed, Norham & 89 & 36 & 1 \\
\hline Wear, Sunderland Br. & 18 & 1 & 0 \\
\hline Swale, Catterick & 122 & 35 & 5 \\
\hline Swale, Thornton & 50 & 0 & 2 \\
\hline Ure, Boroughbridge & 111 & 30 & 9 \\
\hline Wharfe, Tadcaster & 56 & 8 & 5 \\
\hline Nidd, Skip Bridge & 14 & 2 & 8 \\
\hline \multicolumn{4}{|l|}{ Lowland } \\
\hline Derwent & 56 & 9 & 2 \\
\hline Ouse, Acaster & 33 & 0 & 6 \\
\hline Ouse, Clifton Bridge & 45 & 6 & 6 \\
\hline Calder, Methley Br. & 5 & 1 & 13 \\
\hline Aire, Beal Bridge & 2 & 0 & 10 \\
\hline Don, Sprotborough Br. & 2 & 0 & 10 \\
\hline Trent, Cromwell Lock & 0 & 0 & 6 \\
\hline Great Ouse & 0 & 0 & 0 \\
\hline Thames & 1 & 0 & 0 \\
\hline
\end{tabular}



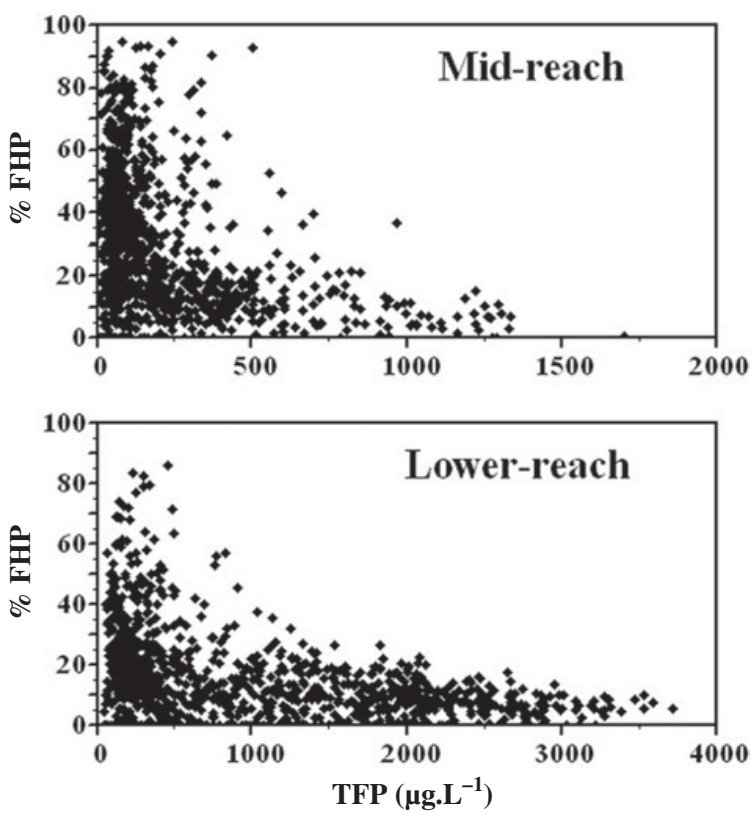

Fig. 1. Comparison of plots of FHP as \% TFP versus TFP concentration for mid-reach and lower-reach sites. Plots are shown for TFP $\leq 500 \mu \mathrm{g} . \mathrm{L}^{-1} \mathrm{TFP}$ to exclude outlier points and show results for lower concentrations more clearly.

As FHP may contain a significant organic phosphorus fraction, the results were broadly assessed to see if FHP correlated with dissolved organic carbon, remembering that DOC contains many organic compounds, some of which are likely to have phosphorus associated with them. This was checked for the whole dataset and individual river systems. In almost all cases there was no statistically significant relationship and the clearest case where there might be a relationship was for the Swale (Fig. 2). Even here there is scatter to the data and there seem to be two linear features of different gradient. Under baseflow conditions a linear feature is found when only the bottom $10 \%$ of flows for each of the LOIS monitoring points is considered. In this case, a strong linear correlation was observed (excluding occasional outliers for FHP $>500 \mu \mathrm{g} . \mathrm{L}^{-1}$ ) with a statistically insignificant intercept:

$$
\begin{aligned}
& \operatorname{FHP}\left(\mu \mathrm{g} . \mathrm{L}^{-1}\right)=23.1 \pm 3.1 * \mathrm{DOC}\left(\mathrm{mg} . \mathrm{L}^{-1}\right) \\
& r^{2}=0.452, n=84
\end{aligned}
$$

This line corresponds to a line passing through the data cloud of steeper slope observed in Figure 2.

\section{Discussion}

The present data together with the literature show that FHP is sometimes quantitatively important at upland, mid- and downriver sites. FHP contributed $20 \%$ or more to TFP at all but the most effluent contaminated sites (Wear, Trent, Great Ouse, Thames). For such sites it seems satisfactory to assume FRP is an adequate indica-
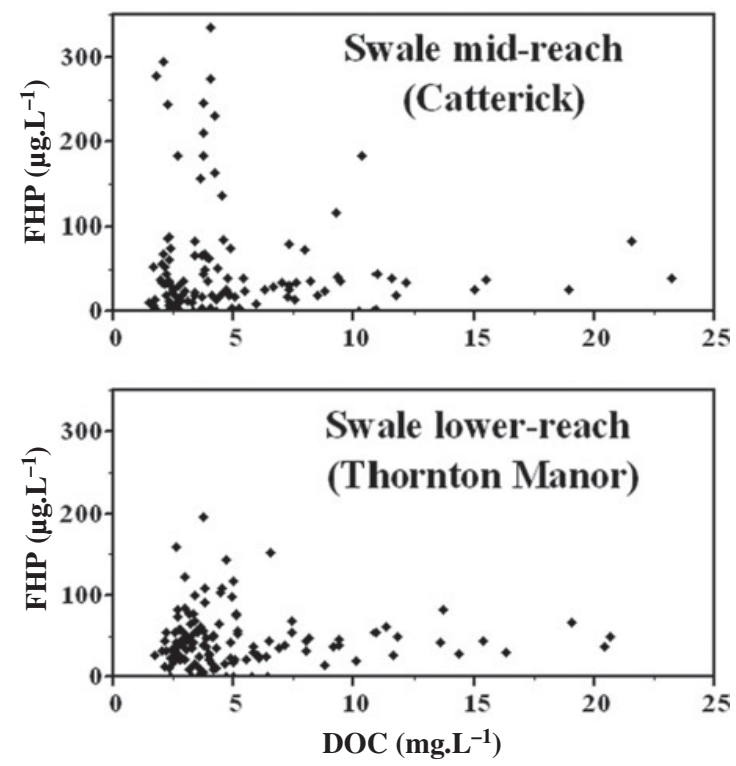

Fig. 2. Plots of FHP against DOC for the Swale at a mid-reach site (Catterick) and a lower-reach one (Thornton Manor).

tion of phosphate for most monitoring purposes, although even in lowland contaminated systems FHP can remain significant (Neal et al., 2010). However, the large number of records at mid-reach sites where FHP could have relatively high concentrations at times (Fig. 1) and, in the case of the Tweed, almost half the time (Table 3), means that FHP should be included in surveys of these rivers. FHP is likely to be most important to algae and bryophytes when TFP is relatively low, such as occurred at $25 \%$ records for five mid-reach sites, based on the criterion of FHP being $>50 \mu \mathrm{g} . \mathrm{L}^{-1}$ at the same time as TFP was $\leq 200 \mu \mathrm{g} . \mathrm{L}^{-1}$ (Table 3 ).

Unfortunately, there are fewer data in the literature about FHP at sites upstream of those considered in the LOIS programme, yet this is where organic phosphate is probably most important for phototrophs. One of the difficulties in assessing phosphorus speciation, especially when concentrations are relatively low, is the effects of sample degradation and storage (Jarvie et al., 2002). Although there was an infrastructure within the LOIS programme to ensure rapid analysis, this was not always possible, especially for samples in remote upland areas. In addition, weekly monitoring may well miss extremes. In the absence of analytical data on the phosphorus composition of FHP, the best evidence comes from the organisms themselves. In the case of the R. Swale at Catterick Bridge, which is $49.9 \mathrm{~km}$ downstream of the source of the main river, FHP was on average $35 \%$ TFP (Table 2). Surface phosphomonoesterase activity of two moss species was about five times higher at a site $10.9 \mathrm{~km}$ downstream of the source than at Catterick Bridge, which

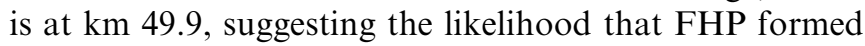
a higher percentage of TFP at the former (Christmas and Whitton, 1998). FHP formed 85 and 61\% TFP in two tributary streams entering the upper part of the 
river and surveyed monthly during 2000-2001 (Ellwood et al., 2008). Subsequent to the LOIS programme, several other studies have shown the importance of FHP in rivers draining peaty catchments. Jarvie et al. (2008) found a mean value of $55 \%$ TFP at a site on $\mathrm{R}$. Taw (Peterford Bridge) draining Dartmoor in South-West England.

None of the upland sites in the present study where FHP at times exceeded $1000 \mu \mathrm{g} . \mathrm{L}^{-1} \mathrm{P}$ were downstream of an important source of organic pollution and it seems probable that most FHP here originated from drainage of peat or soils derived from peat. In the small streams in Upper Teesdale (north of R. Swale upper catchment) showing FHP values of about $1000 \mu \mathrm{g} . \mathrm{L}^{-1} \mathrm{P}$ in spring (Livingstone and Whitton, 1984) the water combines drainage from peat and underlying limestone. They were all distant from human activity, apart from very low density sheep grazing. The dominant phototrophs here and at many other sites draining peat show high surface phosphatase activity (Whitton et al., 1991, 2005), suggesting that much of the FHP here is organic phosphate. Release of motile hormogonia (filaments) from colonies of the cyanobacterium Rivularia takes place when the filaments are P-rich in late spring following a period of elevated phosphate at the Upper Teesdale sites (Whitton et al., 1998) and probably also R. Muga draining the Pyrenees in NE Spain (Mateo et al., 2010). However, there was no seasonal pattern in the seven monthly values when FHP exceeded $1000 \mu \mathrm{g} . \mathrm{L}^{-1} \mathrm{P}$ at the two R. Swale sites (Table 3) during the LOIS study, so it remains unclear to what extent seasonal changes in the concentration and relative importance of FHP may be important for phototroph growth here.

An extreme example of an organism whose competitive success almost certainly depends on the presence of organic phosphate is the diatom Didymosphenia geminata (Whitton et al., 2009). Rivers and streams with Didymophenia often drain catchments with peaty soils overlying base-rich rocks, such as the one in the R. Swale catchment where FHP formed on average $85 \%$ TFP (Ellwood et al., 2008). It has been suggested that recent increases in this diatom, reaching major nuisance proportions in some countries, such as south-east Poland (Kawecka and Sanecki, 2003) and South Island of New Zealand (Kilroy, 2004) may have been influenced by increases in the concentration of organic phosphate draining peat and other organic-rich soils (Ellwood and Whitton, 2007). Dissolved organic carbon (DOC) is also known to be increasing in upland areas of the UK (Worrall et al., 2004), but the present study showed no increase in FHP at R. Swale sites when DOC increased (Fig. 2). The highest values for FHP all occurred when DOC was relatively low and this matches the observation across the sites of a positive correlation for baseflow waters. DOC appears to be too crude a measure to have any value in indicating the relative importance of organic phosphate at sites, but it be worth assessing whether its separation into coloured and non-coloured components (Tipping et al., 2009) might give more information while the use of newer approaches such as tangential flow ultrafiltration will allow assessment of the colloidal fraction.

The origin of FHP at downstream sites is less clear. Presumably it includes FHP originating upstream, but not yet used by organisms or hydrolyzed by soluble phosphatases in the water. Other potential sources include drainage from agricultural soils and effluents from sewage treatment works (STW). A comparison (Jarvie et al., 2010) of eight lowland stream sites draining different types of agricultural catchment found no systematic difference in FHP concentration between high and low agricultural intensity streams, whereas there was with FRP and TP. FHP was, however, important at a site strongly influenced by farm manure/slurry. In contrast, it seems probable that modern sewage treatment effluents have a relatively low proportion of their P content as FHP. The mean value for FHP in several Thames Basin effluents during 2000-2009 was $9 \%$ TFP, although the range was $0-51 \%$ (C. Neal and M. Neal, unpublished data based on 396 individual $\%$ values). Neal et al. (2005) reported a value of $6.6 \%$ TFP for an upstream effluent in the Thames Basin, but subsequent phosphorus stripping at the STW led to a major reduction in FRP, though little reduction in FHP and the $\%$ value (but not concentration) therefore increased (Neal et al., 2005). There is a lack of analytical data to assess whether FHP is more likely to consist largely of organic phosphate at upland or at lowland sites. For the polluted sites especially, there is a need to examine if there are chemical interferences in the FRP methodology that might lower the response, such as highly reducing conditions that would be obviated in the persulphate oxidation step leading to FHP measurement.

It is clear that FHP should be included more widely in routine surveys of water chemistry, especially in upland regions. In turn there is a need for much greater understanding of the composition and dynamics of FHP in rivers. This would require the development of a routine procedure for measuring organic phosphorus, but excluding inorganic polyphosphate and colloidal fractions. The approach should include a detailed comparison for different types of water of the influence of filter type and porosity in order to assess whether there are characteristic changes in composition on passing from upland streams to an estuary. It would allow some critical issues to be addressed. For instance, is there a steady decrease in the relative importance of easily hydrolyzable organic phosphates in the total organic P fraction? If so, the decreasing importance of algal and bryophyte surface phosphatase activity on passing downstream might not just be due to the higher concentration of inorganic phosphate available, but also to FHP becoming increasingly refractory.

Acknowledgements. We thank the various people who have discussed these results with us, especially Dr Neil Ellwood (Università Roma Tre), Prof. Pilar Mateo (Universidad Autonóma, Madrid) and Prof. Paul Withers (Bangor University, Wales) for suggestions on early drafts of this paper. 


\section{References}

American Public Health Association, 2005. Standard Methods for the Examination of Water and Wastewater, 21st edn., Washington, DC.

Baldwin D.S., 1998. Reactive "organic" phosphorus revisited. Wat. Res., 32, 2265-2270.

Christmas M. and Whitton B.A., 1998. Phosphorus and aquatic bryophytes in the Swale-Ouse river system, north-east England. 1. Relationship between ambient phosphorus, internal N:P ratio and surface phosphatase activity. Sci. Total Environ., 210/211, 389-399.

Denison F.H., Haygarth P.M., House W.A. and Bristow A.W., 1998. The measurement of dissolved phosphorus compounds: evidence for hydrolysis during storage and implications for analytical definitions in environmental analysis. Int. J. Environ. Anal. Chem., 69, 111-123.

Eisenreich S.J., Bannerman R.T. and Armstrong D.E., 1975. A simplified phosphorus analysis technique. Environment Letters, 9, 43-53.

Ellwood N.T.W. and Whitton B.A., 2007. Importance of organic phosphate hydrolyzed in stalks of the lotic diatom Didymosphenia geminata and the possible impact of climatic and atmospheric changes. Hydrobiologia, 592, 121-133.

Ellwood N.T.W., Turner B.L., Haile S.M. and Whitton B.A., 2007. Seasonal changes in the surface phosphatase kinetics of aquatic mosses in northern England. J. Bryol., 29, 174-182.

Ellwood N.T.W., Haile S.M. and Whitton B.A., 2008. Aquatic plant nutrients, moss phosphatase activities and tissue composition in four upland streams in northern England. J. Hydrol., 350, 246-260.

Haygarth P.M., Warwick M.S. and House W.A., 1997. Size distribution of colloidal molybdate reactive phosphorus in river waters and soil solution. Wat. Res., 31, 439-448.

Heath R.T., 2005. Microbial turnover of organic phosphorus in aquatic systems. In: Turner B.L., Frossard E. and Baldwin D.S. (eds.), Organic phosphorus in the environment, CAB International, Wallingford, 183-203.

House W.A. and Warwick M.S., 1998. Intensive measurements of nutrient dynamics in the River Swale. Sci. Total Environ., 210/211, 117-137.

Jarvie H.P., Whitton B.A. and Neal C., 1998. Nitrogen and phosphorus in east coast British rivers; Speciation, sources and biological significance. Sci. Total Environ., 210/211, 79-109.

Jarvie H.P., Withers P.J.A. and Neal C., 2002. Sampling, storage, speciation and sensitivity: considerations towards robust measurement of phosphorus in rivers. Hydrol. Earth Syst. Sc., 6, 113-131.

Jarvie H.P., Haygarth P.M., Neal C., Butler P., Smith B., Naden P.S., Joynes A., Neal M., Wickham H., Armstrong L., Harman S. and Palmer-Felgate E.J., 2008. Stream water chemistry and quality along an upland-lowland rural landuse continuum, south-west England. J. Hydrol., 350, 215231.

Jarvie H.P., Withers P.J.A., Bowes M.J., Palmer-Felgate E.J., Harper D.M., Wasiak K., Wasiak P., Hodgkinson R.A., Bates A., Stoate C., Neal M., Wickham H.D., Harman S.A. and Armstrong L.K., 2010. Streamwater phosphorus and nitrogen across a gradient in rural-agricultural land use intensity. Agricult. Ecosyst. Environ., 135, 238-252.
Kawecka B. and Sanecki J., 2003. Didymosphenia geminata in running waters of southern Poland - symptoms of change in water quality? Hydrobiologia, 495, 193-201.

Kilroy C., 2004. A new alien diatom, Didymosphenia geminata (Lyngbye) Schmidt: its biology, distribution, effects and potential risks for New Zealand fresh waters, NIWA, Christchurch.

Lambert D. and Maher W., 1994. An evaluation of the efficiency of the alkaline persulphate digestion method for the determination of total phosphorus in turbid waters. Wat. Res., 29, 7-9.

Leeks G.J.L., Neal C., Jarvie H.P., Casey H. and Leach D.V., 1997. The LOIS river monitoring network: strategy and implementation. Sci. Total Environ., 194/195, 101-109.

Livingstone D. and Whitton B.A., 1984. Water chemistry and phosphatase activity of the blue-green alga Rivularia in Upper Teesdale streams. J. Ecol., 72, 405-421.

Mateo P., Berrendero E., Perona E., Loza V. and Whitton B.A., 2010. Phosphatase activities of cyanobacteria as indicators of nutrient status in a Pyrenees river. Hydrobiologia, 652, 255-266.

McElvie I.D., 2005. Separation, preconcentration and speciation of organic phosphorus in environmental samples. In: Turner B.L., Frossard E. and Baldwin D.S. (eds.), Organic phosphorus in the environment, CAB International, Wallingford, $1-21$.

Murphy J. and Riley J.P., 1962. A modified single solution method for the determination of phosphate in natural waters. Anal. Chim. Acta, 282, 401-450.

Neal C. and Robson A.J., 2000. A summary of river water quality data collected within the Land Ocean Interaction Study: core data for Eastern UK rivers draining to the North Sea. Sci. Total Environ., 251/252, 585-665.

Neal C., House W.A., Leeks G.J.L., Whitton B.A. and Williams R.J., 2000a. The water quality of UK rivers entering the North Sea. Sci. Total Environ., 251/252, 5-8.

Neal C., Jarvie H.P., Whitton B.A. and Gemmell J., 2000b. The water quality of the River Wear, north-east England. Sci. Total Environ., 251/252, 153-172.

Neal C., Jarvie H.P., Williams R.J., Pinder L.C.V., Collett G.D., Neal M. and Bhardwaj L., 2000c. The water quality of the Great Ouse. Sci. Total Environ., 251/252, 423-440.

Neal C., Williams R.J., Neal M., Bhardwaj L.C., Wickham H., Harrow M. and Hill L.K., 2000d. The water quality of the River Thames at a rural site downstream of Oxford. Sci. Total Environ., 251/252, 441-458.

Neal C., Jarvie H.P., Neal M., Love A.J., Hill L. and Wickham H., 2005. Water quality of treated sewage effluent in a rural area of the upper Thames Basin, southern England, and the impacts of such effluents on riverine phosphorus concentrations. J. Hydrol., 304, 103-117.

Neal C., Jarvie H.P., Williams R.J., Love A., Neal M., Wickham H., Harman S. and Armstrong L., 2010. Declines in phosphorus concentration in the upper River Thames (UK): Links to sewage effluent cleanup and extended end member mixing analysis. Sci. Total Environ., 408, 1315-1330.

Robson A.J. and Neal C., 1997. Regional water quality of the river Tweed. Sci. Total Environ., 194/195, 173-192.

Tipping E., Corbishley H.T., Koprivnjak J.F., Lapworth D.J., Millerd M.P., Vincent C.D. and Hamilton-Taylor J., 2009. Quantification of natural DOM from UV absorption at two wavelengths. Environ. Chem., 6, 472-476. 
Turner B.L., 2005. Organic phosphorus transfer from terrestrial to aquatic environments. In: Turner B.L., Frossard E. and Baldwin D.S. (eds.), Organic phosphorus in the environment, CAB International, Wallingford, 269-294.

Turner B.L., Baxter R. and Whitton B.A., 2003. Nitrogen and phosphorus in soil solutions and drainage streams in Upper Teesdale, northern England: Implications of organic compounds for biological nutrient limitation. Sci. Total Environ., 314/316, 153-170.

Whitton B.A., Grainger S.L.J., Hawley G.R.W. and Simon J.W., 1991. Cell-bound and extracellular phosphatase activities of cyanobacterial isolates. Microb. Ecol., 21, 85-98.

Whitton B.A., Yelloly J.M., Christmas M. and Hernández I., 1998. Surface phosphatase activity of benthic algal communities in a stream with highly variable ambient phosphate concentrations. Verh. Int. Verein. Limnol., 26, 967-972.
Whitton B.A., Al-Shehri A.M., Ellwood N.T.W. and Turner B.L., 2005. Ecological aspects of phosphatase activity in cyanobacteria, eukaryotic algae and bryophytes. In: Turner B.L., Frossard E. and Baldwin D.S. (eds.), Organic phosphorus in the environment, CAB International, Wallingford, 205-241.

Whitton B.A., Ellwood N.T.W. and Kawecka B., 2009. Biology of the freshwater diatom Didymosphenia: A review. Hydrobiologia, 630, 1-37.

Withers P.J.A., Hodgkinson R.H., Adamson A. and Green G., 2007. The impact of pasture improvement on phosphorus concentrations in soils and streams in an upland catchment in Northern England. Agricult. Ecosyst. Environ., 122, 220-232.

Worrall F., Burt T.P. and Adamson J.K., 2004. Trends in dissolved carbon in UK rivers and lakes. Biogeochemistry, $70,369-402$. 